\title{
Historical Evolution of the Trophic and Limnological Relationships in the Itaipu Reservoir: Top-Down and Bottom-Up Effects upon Fish Production
}

\author{
Rinaldo Antonio Ribeiro Filho', Miguel Petrere Junior ${ }^{2,3}$, Ângelo Antonio Agostinho4, \\ Simone Friderigi Benassi5 ${ }^{5}$, Julia Myriam de Almeida Pereira1, Edson Kiyoshi Okada4 \\ ${ }^{1}$ Curso de Engenharia de Pesca, Universidade Estadual Paulista (Unesp), Registro, Brazil \\ ${ }^{2}$ Programa de Pós Graduação em Diversidade Bilógica e Conservação, Universidade Federal de São Carlos \\ (UFSCar), Sorocaba, Brazil \\ ${ }^{3}$ Programa de Pós Graduação em Sustentabilidade em Ecossistemas Marinhos e Costeiros, UNISANTA, Santos, \\ Brazil \\ ${ }^{4}$ Departamento de Biologia, Núcleo de Pesquisas em Limnologia, Ictiologia e Aquicultura, Universidade \\ Estadual de Maringá, Paraná, Brazil \\ ${ }^{5}$ Divisão de Reservatório (MARR.CD), Itaipu Binacional, Foz do Iguaçu, Brazil \\ Email: rinaldo@registro.unesp.br
}

Received 16 March 2015; accepted 6 June 2015; published 10 June 2015

Copyright (C) 2015 by authors and Scientific Research Publishing Inc.

This work is licensed under the Creative Commons Attribution International License (CC BY).

http://creativecommons.org/licenses/by/4.0/

(c) (i) Open Access

\begin{abstract}
Many experimental studies have contributed to the development of the theory of trophic chains in lacustrine habitats. They have revealed the important role played by fish, a subject that has been mostly ignored by limnological studies for the past few decades. Most of these studies were developed in Europe and in the United States. The general applicability of this theory has not yet been tested in subtropical and tropical habitats. In spite of controversies, the bottom-up: topdown trophic cascade hypotheses are the most adopted conceptual models. In this context, we examined if these hypotheses may be corroborated by data from the subtropical Itaipu Reservoir. A negative effect was verified between water transparency and total suspended solids. The detritivorous fish exerted a controlling effect on chlorophyll-a concentrations. Bottom-up effects were detected in four trophic levels, and top-down was detected in just one trophic level. The limnological variates influenced the chlorophyll-a concentration, which indicated that the InTKN plus the effect of the quarter and the reservoir zone (and their interaction) were important.
\end{abstract}




\section{Keywords}

\section{Reservoir Trophic Cascade, Top-Down, Bottom-Up, Limnology, Biotic Community}

\section{Introduction}

Trophic cascades are based on the transfer of food energy from autotrophic organisms, through organisms that consume it and are themselves later consumed [1].

The metabolism of an aquatic ecosystem has three main stages: i) production; ii) consumption and iii) decomposition [2], each of which depends upon the light and transparency of aquatic ecosystems [3] [4]. The trophic chain is defined as the interaction among the stages of this metabolism cycle.

According to [5], in the structure of a freshwater ecosystem, there are abiotic components (e.g., inorganic substances, nutrients, organic components and climatic traits) and biotic components (e.g., producers, macroconsumers such as zooplankton and fish, and micro-consumes and autotrophic and heterotrophic organisms). These functions are essential to understanding ecosystem dynamics and can be functionally analyzed according to energy flow, nutrient cycling, development patterns and the productivity of the organisms in time/space, as well as the food chains and control (cybernetic and metabolism regulation). The transfer of energy from a given level to another is explained by the pressure that the zooplankton exerts upon the phytoplankton and fish predation of the plankton. Each transfer from one level to another generates a loss of potential energy of between 80 and $90 \%$. The food chains may inter-link with other chains forming a system complex, that is, the trophic food web. These chains can be divided into two groups: i) the food chain starting with phytoplankton, moving to zooplankton and finishing with fish or ii) the detritus food chain, starting with the degradation of the organic matter by microorganisms, moving to detritivores and finishing with fish.

The pioneering paper by [6] highlighted the effect of fish on the food chain structure. Afterwards, [7] contributed to the development of the trophic lacustrine chain by revealing the important role played by fish. The theories of trophic cascade [8] [9] and of bottom-up: top-down [10] are the main conceptual models used currently. Reference [11] reviewed the trophic cascade theory and the population control in lakes, suggesting that understanding the food chain could be useful for management purposes.

The trophic cascade theories ([8]; see the criticisms of [9], and meta-analyses in [12] [13]) and bottom-up: top-down theories [10] are the two main conceptual models discussed in this paper. The greatest effects of fish and herbivore zooplankton usually take place in oligotrophic [10] or mesotrophic systems [14]. Phytoplankton responds positively to the nutrient enrichment in those ecosystems with odd trophic nets (the three levels are phytoplankton, zooplankton and planktivorous fish) but not in ecosystems with pair trophic nets (two levels without fish or four levels with piscivorous fish).

The effect of the planktivorous fish stock upon the zooplankton community has been studied in tropical habitats [15], and there is strong pressure from these fish exerted on the algae biomass [16]. The indirect effect of piscivores on planktivores stock is very strong [9] [17] [18]. Some studies confirm that the impact of fish stocking enhances chlorophyll concentrations through the excretion of nutrients and predation upon zooplankton [19][21]. When discussing the stocking of piscivorous fish, many papers did not report success [9] [19] due to factors such as low stockpiling density [22]. In many papers, the top-down effect was observed [7] [8] [11] [17] [23] [24].

According to [25], a pattern can be seen between the herbivores' consumption efficiency in terrestrial and aquatic communities. In these communities, the consumption by herbivores is higher (32\%) than in terrestrial systems (3\%), and this difference can be attributed to the role that the primary and secondary predators play in the two systems. In freshwater lakes, secondary predators are an important component, reducing the number of primary carnivores and, therefore, the predation pressure upon herbivores. In terrestrial communities, secondary carnivorous communities are not quantitatively important to the mortality of primary carnivores. Primary predation is a main source of herbivores' mortality, so allowing an increase of the primary producers shows a topdown effect in community control.

Reference [26] compared data from limnological trophic variates with temporal and spatial fish distribution, zooplankton and phytoplankton and concluded that the trophic level distribution was correlated with water temperature and nutrient concentrations. 
Reference [27] studied 31 Argentinean reservoirs, demonstrating that in those habitats in which piscivorous do not cause zooplanktophagous depletion, the phytoplankton biomass was drastically reduced. The authors emphasized that human influence may induce changes in trophic relationships in lakes and reservoirs.

References [28] [29] studied the period ranging from 1999 to 2004 in the Itaipu reservoir analyzing the relationships among chlorophyll-a, cyanobacteria and water transparency and their effect on other limnological variates. They were attempting to detect the existence of some effect from these variates on the trophic cascade. The direct effects of top-down and bottom-up were confirmed. The top-down forces were only found in the first trophic level, whereas the bottom-up forces were found in the other levels. The indirect effects showed that the fish guilds that control the water quality were omnivorous, insectivorous and detritivorous fish. The piscivorous types did not control chlorophyll-a concentrations but controlled other fish groups, thereby worsening water quality.

Fish feeding studies, when showing trophic interactions such as predation, competition and grazing, help us to understand the trophic functions of lakes and reservoirs. These studies may help to manage the fish stock under the ecosystem approach to fisheries [30] or even improve the water control, as well as the cultivation of confined organisms.

This work is based on the hypothesis that the trophic relationships in a cascade, particularly those related to the bottom-up and top-down effects, may be detected in the Reservoir of Itaipu, a system found in the subtropical area. Knowledge of functions of the food chain, with connections between the limnology and the fisheries, could be used as biological alternative for reservoir management. The increment of some trophic groups of fish could reduce the density of planktivorous fish and, as a consequence, increase the herbivory (grazing) and depletions in chlorophyll concentrations.

The objectives of this paper are two-fold: i) to characterize the trophic chains and ii) to characterize the relationships among fish relative biomass, plankton and Itaipu reservoir limnology examining models to understand the relationships between fish production and reservoir limnological and biological variates.

\section{Material and Methods}

\subsection{Study Area}

This research was conducted at multiple locations in Itaipu Reservoir, a large (1,460,000 ha), dendritic reservoir. The Paraná River is the $10^{\text {th }}$ longest in the world (4695 km). It is formed by the confluence of rivers Grande and Parnaíba (Southeast Brazil), and its lower portion is known as La Plata River [31]. The Paraná River basin supplies more than $70 \%$ of the hydroelectric energy in the country by its 130 dams (Figure 1).

To select the sampling sites, we took into consideration the three classic sectors along a large reservoir [32] corroborated by sedimentation rates and biotic and abiotic gradients [33]. These sectors were the i) fluvial zone (river area), which is located at the beginning of the reservoir; ii) transition zone, where the particulate sediment is deposited and iii) lentic zone (lacustrine area), which is an area close to the dam where the reservoir is usually wider, deeper and nutrient poor. The Itaipu reservoir is dendritical, and its arms are mostly independent of the central body, with each having its own characteristics. In view of these three sectors, we established a monitoring program with 12 sampling stations, which we believed to be representative of the whole body of water.

\subsection{Data}

The physical, chemical and biological variates were provided by ITAIPU BINACIONAL and determined from water samples collected from the surface in the months of February, May, August and November from 1985 to 2008 in the three main reservoir areas (fluvial, transition and lacustrine). The variates temperature, concentration of the dissolved oxygen and saturation percentage, $\mathrm{pH}$, electric conductivity and water transparency. Analyses of the other physical and chemical variates, such as alkalinity, nitrate, nitrite, ammoniacal nitrogen, nitrogen Kjeldahl (TKN), suspended solids, DQO, DBO and total phosphorous, were performed in the laboratory were measured in situ. The methodologies used in limnologicalanalyses, phytoplankton analyses and zooplankton analyses are descript in [28] (2006) (Table 1).

Small-scale fisheries catch data were provided by a program of fisheries statistics, consisting of interviews of the professional fishers at landing and eviscerated and beheaded catches expressed in fish weight (kg). This was done monthly from 1987 to 2006 in the three reservoir areas and grouped in quarters to be properly compared 


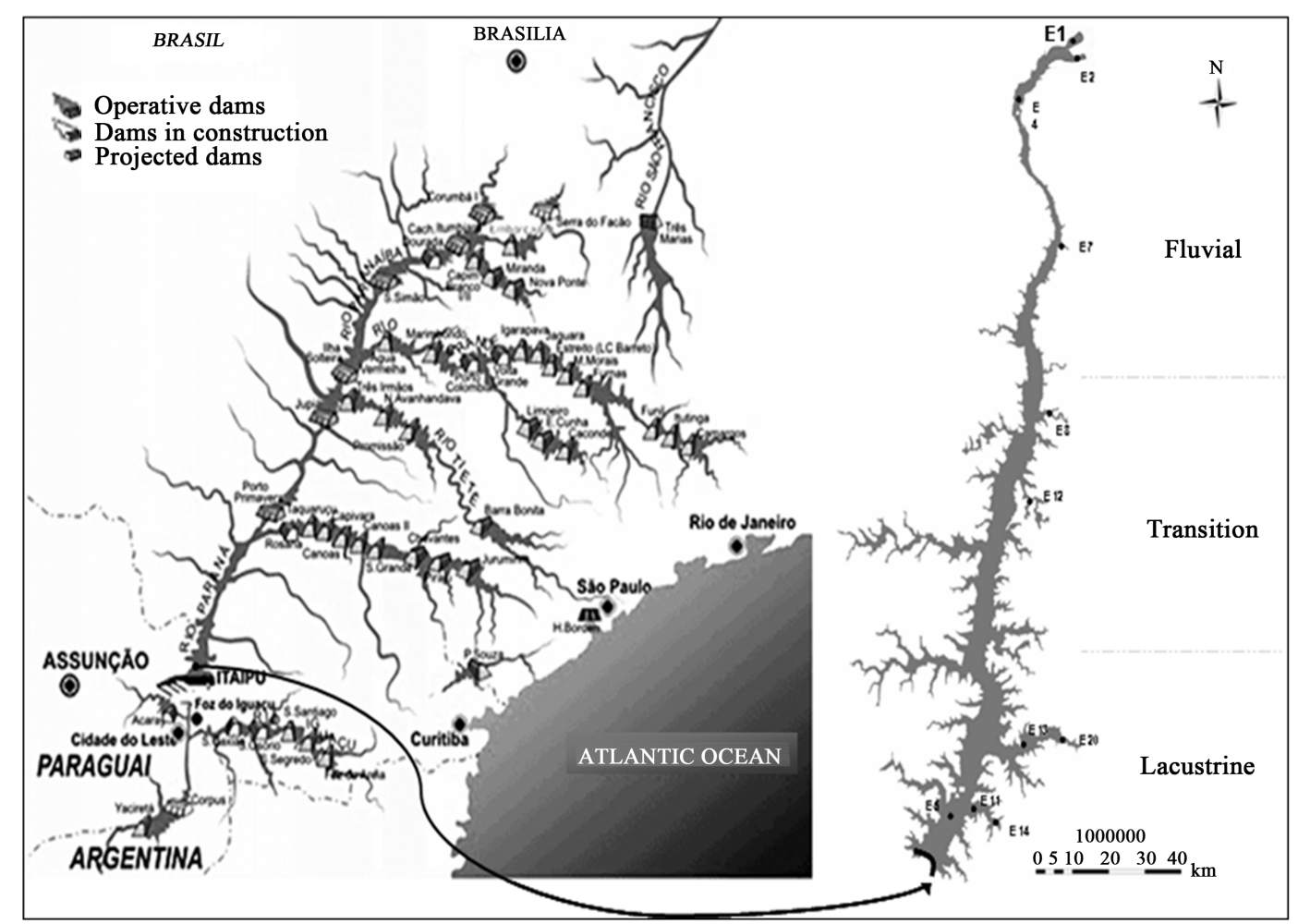

Figure 1. Paraná River basin, with its main dams. In the detail, the Itaipu Reservoir morphometry and the previously adopted sampling sites in the fluvial, transition and lacustrine zones.

Table 1. Limnologicalvariates, units, analysis methods and sampling frequency from data obtained in Itaipu reservoir at each quarter, from 1987 to 2006.

\begin{tabular}{|c|c|c|}
\hline Variate & Unit & Method \\
\hline Temperature & ${ }^{\circ} \mathrm{C}$ & WTW mod. OXI 196 \\
\hline Dissolved Oxygen & $\mathrm{mg} / \mathrm{L}$ & WTW mod. OXI196 \\
\hline$\%$ OD Saturation & $\%$ & WTW mod. OXI196 \\
\hline $\mathrm{pH}$ & Units & Potentiometer WTW mod. 196 \\
\hline Conductivity & $\mu \mathrm{S} / \mathrm{cm}$ & WTW mod. LF 191 \\
\hline Transparence & M & Secchi disk \\
\hline Total alkalinity & $\mathrm{mg} / \mathrm{L}$ & Titration method (APHA, 1992). \\
\hline Nitrate & $\mathrm{mg} / \mathrm{L}$ & АРНA (1992). \\
\hline Nitrite & $\mathrm{Mg} / \mathrm{L}$ & APHA (1992) \\
\hline Ammoniacal nitrogen & $\mathrm{Mg} / \mathrm{L}$ & Spectrophotometry (detection limit $<0.02 \mathrm{mg} \cdot \mathrm{L}^{-1}$ de N (APHA, 1992). \\
\hline Total nitrogen Kjeldahl (TKN) & $\mathrm{Mg} / \mathrm{L}$ & Phenate method (APHA, 1992). \\
\hline Turbidity & NTU & Turbidimeter HACH, model 2100 A (APHA, 1985). \\
\hline DQO & $\mathrm{Mg} / \mathrm{L}$ & APHA (1992) \\
\hline DBO & $\mathrm{Mg} / \mathrm{L}$ & APHA (1992)). \\
\hline Total phosphorous & $\mathrm{Mg} / \mathrm{L}$ & Ascorbic Acid Method (APHA (1992)). \\
\hline Suspended solids & $\mathrm{Mg} / \mathrm{L}$ & APHA (1992) \\
\hline Chlorophyll- $a$ & $\mathrm{mg} / \mathrm{m}^{3}$ & $\begin{array}{l}\text { Spectrophotometry DMS 100, wavelengths } 750 \mathrm{~nm} \text { and } 665 \mathrm{~nm} \text {, } \\
\text { according to the NUSCH (1980) method. }\end{array}$ \\
\hline Phytoplankton & Cell $/ \mathrm{mL}$ & UTERMÖHL (1958) sedimentation method \\
\hline Zooplankton & Organisms/mL & $\begin{array}{l}\text { Rothiphera: Sedgwick-Rafter cells counts } \\
\text { CladoceraandCopepoda: Bogorovcamera }\end{array}$ \\
\hline
\end{tabular}


with the afore-mentioned limnological data, which was supplied by UEM-Nupelia (Universidade Estadual de Maringá).

\subsection{Data Analysis-Phytoplankton, Zooplankton and Fish}

Phytoplankton data are presented numerically (organisms $/ \mathrm{mL}$ ) in terms of relative abundance and separated into four classes, namely Cyanophyceae, Chlorophyceae, Bacillariophyceae and Phytoflagelata. Zooplankton data are presented in the same way and separated into Rotifera (microzooplankton), Cladocera and Copepoda (macrozooplankton, both).

The relative abundances in each trophic guild are expressed by eviscerated-beheaded fish weight (kg). Fish data are classified into trophic guilds according to [34] (Table 2).

The numeric and relative abundances of the phytoplankton, zooplankton and fish are presented for each reservoir sector to detect and compare patterns.

\subsection{Statistical Analysis}

The physical and chemical variates and the community variates related to phyto and zooplankton in the three reservoir zones are expressed in terms of the averages of readings taken at the surface in each sampling site per quarter. The mean landings $(\mathrm{kg})$ were grouped per quarter for each trophic guild. The weights of beheaded fish were expressed in kilograms.

Preliminarily, the data of all of the variates were examined through a scatter plot for each pair of variates. In most of these, the original relationship was not linear, and the dates were log-log transformed to attain linearity. A correlation analysis was also applied to the pairs of transformed variates, and those that presented a significance of $p<0.05$ were selected for the MANCOVAs and ANCOVA (Table 3). The variates selected were:

- Fishes piscivorous, insectivorous, omnivorous, detritivorous, iliophagous, zooplanctivorous;

- Limnological Variates: turbidity, Secchi depth, alkalinity, TKN, suspended solids, oxygen saturation, total phosphorous, $\mathrm{pH}$, dissolved oxygen, conductivity, chlorophyll-a;

- Zooplankton: Rotifera, Cladocera, Copepoda;

- Phytoplankton: Cyanobacteria, Chlorophyceae, Diatoms, Phytophlagelates.

- The analyses were done according to the food chain models (top-down and bottom-up) suggested by [10] [11] [20] [35].

\subsection{MANCOVAS}

The first MANCOVA was performed to test the bottom-up effect in the reservoir, checking the effects of the limnological variates on primary production. The two dependent variates were cyanobacteria concentration (lncyan, logarithm of the cyanobacteria concentration, expressed in cell/mL) and Secchi disk reading (lnsd, logarithm of depth of the Secchi disk, expressed in $\mathrm{m}$ ). These variates were chosen to represent the reservoir water quality through water transparency and because a cyanobacteria bloom can worsen water quality for procreation and recreation. To verify which limnological explanatory variates were related to the dependent variates, we included: a) lnturb, logarithm of the turbidity concentration, expressed in NTU; b) lnss, logarithm of suspended solids concentration, expressed in $\mathrm{mg} / \mathrm{L}$; c) lntp, logarithm of the concentration of total phosphorous, expressed in $\mathrm{mg} / \mathrm{L}$; d) lntkn, logarithm of the concentration of TKN, expressed in $\mathrm{mg} / \mathrm{L}$; e) lnchlor, logarithm of the chlorophyll-a concentration, expressed in $\mathrm{mg} / \mathrm{m}^{3}$; and f) lnsox, logarithm of the concentration of dissolved oxygen, expressed in $\mathrm{mg} / \mathrm{L}$. The factors were included: I) Zone, with three levels (fluvial, transition and lacustrine) and II) Quarter, with four levels (1, 2, 3 and 4).

In the second MANCOVA, the objective was to test a top-down effect through the determination of some trophic level which could have influenced the reservoir nutrient forms. The nutrients assimilated by phytoplankton were chosen as dependent variates. These were total phosphorous (lntp, logarithm of concentration of total phosphorous, expressed in mg/L) and TKN (lntkn, logarithm of the concentration of TKN, expressed in $\mathrm{mg} / \mathrm{L}$ ). This variable was chosen as it was the only nitrogenous form with values available in all samplings. The trophic levels were represented by the following explanatory variates: a) lnchlor, logarithm of the chlorophyll-a concentration, expressed in $\mathrm{mg} / \mathrm{m}^{3}$; b) lncyan, logarithm of the cyanobacteria concentration, expressed in cell/mL; c) lnclad, logarithm of the Cladocera concentration, expressed in organism/mL; d) lncop, logarithm of 
Table 2. Trophic guilds and main fish species caught by the small-scale fishers in the Itaipu.reservoir.

\begin{tabular}{|c|c|}
\hline Guild & Scientific name \\
\hline & Rhamdia quelen (Quoy \& Gaimard, 1824) \\
\hline & Clarias gariepinus (Burchell, 1822) \\
\hline & Pinirampus pirinampu (Spix, 1829) \\
\hline & Ageneiosus valenciennesi (Bleeker, 1894) \\
\hline & Plagioscion squamosissimus (Heckel, 1840) \\
\hline & Salminus maxillosus (Valenciennes, 1849) \\
\hline & Acestrorhynchus lacustris (Reinhardt, 1874) \\
\hline & Hemisorubimplatyrhynchos (Valenciennes,1840) \\
\hline & Paulicealuetkeni (Steindachner, 1875) \\
\hline \multirow[t]{13}{*}{ Piscivores } & Hoplerythrinus unitaeniatus (Spix, 1829) \\
\hline & Catathyridiumjenynsi (Günther, 1862) \\
\hline & Synbranchus marmoratus (Bloch, 1795) \\
\hline & Acestrorhynchus lacustris (Reinhardt, 1874) \\
\hline & Galeocharaxknerii (Steindachner, 1879) \\
\hline & Pseudoplatystoma corruscans (Agassiz, 1829) \\
\hline & Serrasalmus marginatus (Valenciennes, 1847 ) \\
\hline & Potamotrygon motoro (Müller \& Henle, 1841) \\
\hline & Hoplias malabaricus (Bloch, 1794) \\
\hline & Cichla monoculus (Spix, 1831 ) \\
\hline & Astronotus ocellatus (Agassiz, 1831) \\
\hline & Pterodoras granulosus (Valenciennes, 1821) \\
\hline & Pimelodus maculatus (Lacépède, 1803) \\
\hline \multirow[t]{7}{*}{ Omnivores } & Parauchenipterus galeatus (Linnaeus, 1766) \\
\hline & Piaractus mesopotamicus (Holmberg, 1887) \\
\hline & Myloplus cf. tiete (Eigenmann \& Norris, 1900) \\
\hline & Leporinus friderici (Bloch, 1794) \\
\hline & Apteronotus albifrons (Linnaeus, 1766) \\
\hline & Crenicichla sp. \\
\hline & Auchenipterusosteomystax (Ribeiro, 1918) \\
\hline \multirow[t]{4}{*}{ Insectivores } & Gymnotus carapo (Linnaeus, 1758) \\
\hline & Rhamphichthys hahni (Meiken, 1937) \\
\hline & Leporinus elongatus (Valenciennes, 1849) \\
\hline & Bryconorbignyanus (Valenciennes,1849) \\
\hline
\end{tabular}




\section{Continued}

Schizodonaltoparanae (Garavello \& Britski, 1990)

Herbivorous

Iliophagous

Zooplanktivores
Schizodonborelli (Boulenger, 1900 )

Tilapia rendalli (Boulenger, 1896)

Hoplosternum littorale (Hancock, 1828)

Trachydoras paraguayensis (Eigenmann \& Ward, 1907)

Satanoperca pappaterra (Heckel, 1840)

Cyprinus carpio (Linnaeus, 1758)

Hypostomus sp.

Loricaria sp.

Prochilodus lineatus (Valenciennes, 1836)

Hypophthalmus edentatus (Spix, 1829)

\section{Table 3. Variates without outliers, obtained from correlation tests.}

\begin{tabular}{cccc}
\hline Fishes & Limnological variates & Zooplankton & Phytoplankton \\
\hline Piscivorous & Turbidity & Rotifera & Cyanobacteria \\
Insectivorous & Secchi depth & Cladocera & Diatoms \\
Omnivorous & Alkalinity & Copepod & Phytophlagelates \\
Detritivorous & TKN & & \\
Iliophagous & Suspended solids & \\
Zooplanctivorous & Oxygen saturation & \\
& Total phosphorous & \\
& pH & \\
& Dissolved oxygen & \\
& Conductivity & \\
\hline
\end{tabular}

the Copepoda concentration, expressed in organism/mL; e) lnpis, logarithm of the biomass of piscivorous fishes, expressed in kg; f) lnomn,logarithm of the biomass of omnivorous fishes, expressed in kg; g) lndetr, logarithm of the biomass of detritivorous fishes, expressed in kg; h) lnilio, logarithm of the biomass of iliophagous fishes, expressed in kg; and i) lnzoopl, logarithm of the biomass of zooplanktophagous fishes, expressed in kg. The factors were considered: I) Zones, with three levels (fluvial, transition and lacustrine); and II) Quarter, with four levels (1, 2, 3 and 4).

Reference [39] affirm that MANCOVA is the most complete linear model, aiming to detect of the effects of one or more factors upon to one or more continuous response variates. The ANCOVA is a particular case of MANCOVA.

After a MANCOVA was carried out and a significance level of 5\% was detected, subsequent ANCOVAs were done to detail the obtained results [36]-[39]. In all cases, the log-log (base e) of response variates and covariates was used.

For the application of MANCOVAs, we assessed the normality and homogeneity of the variance/covariance matrices. A test of the hyperplane's parallelism was also performed. For the ANCOVA, aside from ascertaining their presupposition of parallelism, an appropriate analysis of the residuals was undertaken to confirm normality and variance homogeneity. 


\subsection{ANCOVA}

The ANCOVA was carried out to verify which explanatory limnological variates would determine the effect of the dependent variate chlorophyll (lnchlor, logarithm of the chlorophyll-a concentration, expressed in $\mathrm{mg} / \mathrm{m}^{3}$ ). Like in the first MANCOVA, this variate was considered to be a covariate because it was believed to have an effect on Secchi disk readings, and in the second MANCOVA, chlorophyll was also considered a covariate because of its direct link with the tested nutrient forms. The linological variates are: a) lnturb, logarithm of the turbidity concentration, expressed in NTU; b) lnss, logarithm of suspended solids concentration, expressed in mg/L; c) lntp, logarithm of the concentration of total phosphorous, expressed in $\mathrm{mg} / \mathrm{L}$; and d) lntkn, logarithm of the concentration of TKN, expressed in $\mathrm{mg} / \mathrm{L}$. The factors were considered I) Zone: reservoir areas (fluvial, transition and lacustrine); II) Quarter: quarters (1, 2, 3 and 4); and III) the zone $\times$ quarter interaction of Zone and Quarter.

Aiming to attain a balanced design [40]-[43], the limnological data were classified by quarter (4 levels) and zones ( 3 levels), taken as factors. Scatter plots were drawn between lnchlor $\times$ lnturb, lnchlor $\times$ lnss, lnchlor $\times$ lntp and lnchlor $\times$ lntkn, in which lnchlor is logarithm of the chlorophyll-a concentration, expressed in $\mathrm{mg} / \mathrm{m}^{3}$; lnturb is logarithm of the turbidity concentration, expressed in NTU; lnss is logarithm of suspended solids concentration, expressed in $\mathrm{mg} / \mathrm{L}$; lntp is logarithm of the concentration of total phosphorous, expressed in $\mathrm{mg} / \mathrm{L}$; and lntkn is logarithm of the concentration of TKN, expressed in $\mathrm{mg} / \mathrm{L}$. These graphs were inspected to assess their linearity. The analysis of the residuals were inspected to identify for any tendencies; $\mathrm{g}_{1}$ (coefficient of asymmetry) and $\mathrm{g}_{2}$ (coefficient of kustosis) values were calculated to test their normality.

After these preliminary analyses, we applied a stepwise procedure to the initial two-way ANCOVA model to evaluate which explanatory variates (covariates: lnturb, lnss, lntp and lntkn) determine the chlorophyll-a concentration (lnchlor is the response variate). The analyses clearly have an exploratory character when trying to understand the correlation structure among the variates in search of a minimum model. No significant factors, their interaction or covariates at a 5\% significance level were discarded. The significance level was kept at 5\% due to the stepwise method was conducted manually. In another words, when each test was performed and the values observed, the greatest $\mathrm{p}$ value was removed from the model and, the test, performed again. To compare the pair of adjusted means, we followed the LSD procedure according to [44].

\section{Results}

\subsection{Trophic Interactions Analysis: Direct and Indirect Effects}

To test the trophic cascade hypothesis in the Itaipu reservoir, scatterplots between pairs of variates obtained for the period of study were inspected and correlation analyses were carried out in those pairs with higher grouping along the tendency line. These results showed as direct and indirect effects in Figure 2 and are not shown to scale to represent positive and negative relationships between the variates (trophic level). The direct effects are those in which the energy transfer occurs between subsequent levels, as opposed to the indirect ones, in which the transfer does not occur between subsequent levels.

The piscivorous presented positive and significant relationships with four fish trophic guilds; these were insectivorous ( $p<0.01$ ), benthivorous $(p<0.01)$, zooplanktivorous $(p<0.01)$ and iliophagous $(p<0.01)$ fish. The omnivorous fish also exhibited significant relationships with three fish groups; the negative effects were observed in relation to the zooplanktophagous fish $(p<0.01)$, and the positive effects were observed in relation to the detritivorous $(p<0.01)$ and iliophagous $(p<0.01)$ fish. Almost all groups presented positive and significant relationships with the macrozooplankton (Piscivorous $\times$ Cladocera: $p<0.01$; Piscivorous $\times$ Copepoda: $p<0.01$; Insectivorous $\times$ Cladocera: $p<0.01$; Detritivorous $\times$ Cladocera: $p<0.01$; Detritivorous $\times$ Copepoda: $p<0.01$; Bentophagous $\times$ Cladocera: $p<0.05$; Bentophagous $\times$ Copepoda: $p<0.01$; Iliophagous $\times$ Cladocera: $p<0.01$; Zooplanktophagous $\times$ Cladocera: $p<0.01$; Zooplanktophagous $\times$ Copepoda: $p<0.05$ ). Cladocera and Copepoda presented positive relationships with chlorophyll-a (Cladocera: $p<0.01$; Copepoda: $p<0.05$ ) and the cyanobacteria concentrations (Cladocera: $p<0.01$ ).

The relationship between the macrozooplankton and chlorophyll-a indicated a positive and significant effect.

The relationship of chlorophyll-a $(p<0.01)$ and cyanobacteria $(p<0.01)$ with TKN was positive and significant. Cyanobacteria and total phosphorous were positively correlated $(p<0.05)$.

In the analyses of the indirect interactions, the groups of fish that exhibited relationships with chlorophyll-a 


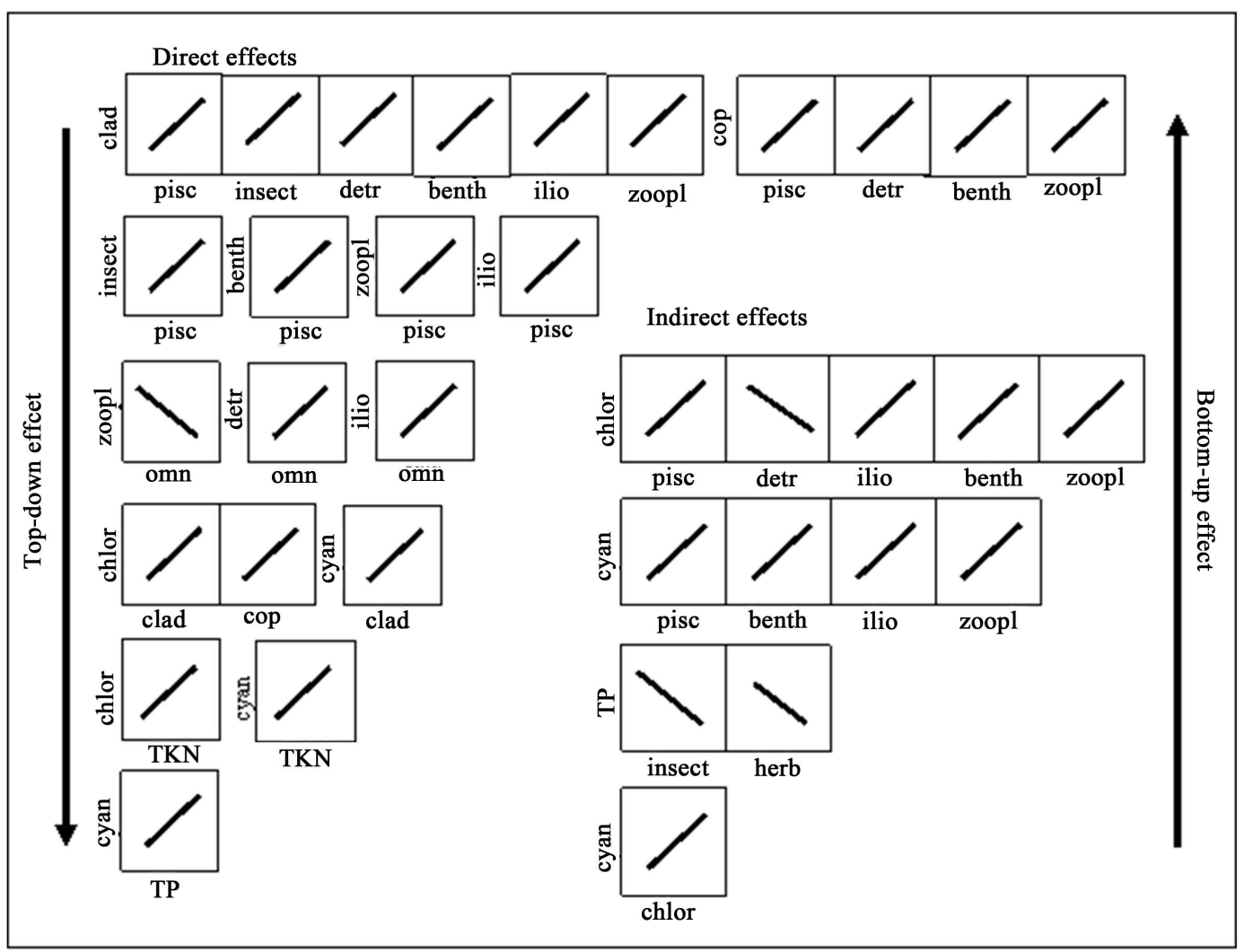

Figure 2. Direct and indirect effects in the trophic cascade in the Itaipu Reservoir from 1984 to 2004, obtained from correlation analyses. pisc = piscivorous fishes; insect = insetivorous fishes; detr = detritivorous fishes; benth = benthivorous fishes; ilio = iliophagous fishes; zoopl = zooplanktivorous fishes; omn = omnivorous fishes; herb = herbivorous fishes; clad = Cladocera; cop = Copepoda; chlor = chlorophyll-a concentration; cyan = Cyanobacteria; $\mathrm{TKN}=$ total Kjeldahl nitrogen concentration; $\mathrm{TP}=$ total phosphorous concentration.

were the piscivorous $(p<0.01)$, the detritivorous $(p<0.01)$, the iliophagous $(p<0.01)$, the bentophagous $(p<$ $0.01)$ and the zooplanktophagous $(p<0.01)$ fish. The groups of fish that presented negative relationships with total phosphorous were the insectivorous $(p<0.01)$ and herbivorous $(p<0.01)$. The piscivorous $(p<0.01)$, the benthivorous $(p<0.05)$, the iliophagous $(p<0.01)$ and the zooplanktophagous $(p<0.01)$ fish presented positive relationships with the cyanobacteria. There was a positive relationship between chlorophyll-a and cyanobacteria $(p<0.01)$.

\subsection{Statistical Analysis}

\subsubsection{MANCOVA 1}

A MANCOVA was applied to the two response variates, cyanobacteria concentration and Secchi disk depth. The factors were Zone and Quarter. The covariates included in the model were lnturb, lnss, lntp, lntkn, lnchlor and lnsox.

The scatterplots between (a) the response variate cyanobacteria concentration and covariates (lncyan $\times$ lnturb, lncyan $\times$ lnss, lncyan $\times$ lntp, lncyan $\times$ lntkn, lncyan $\times$ lnchlor, lncyan $\times$ lnsox) and (b) the response variate Secchi depth and covariates (lnsd $\times$ lnturb, lnsd $\times$ lnss, lnsd $\times$ lntp, lnsd $\times$ lntkn, lnsd $\times$ lnchlor, lnsd $\times$ lnsox) were inspected, and the relationships were linear. The components tested in the initial model were the factors Zone and Quarter. The relationships were linear in the log-log scale but with a high dispersion along the tendency of a straight line, as is usually found in observational field studies.

The MANCOVA results indicated that lnss, lntp and lntkn were not significant. Another MANCOVA was performed, and the tests indicated that the turbidity concentrations and dissolved oxygen, aside from the zone and quarter factors, were statistically significant in relation to the dependent variates (Table 4). 
Table 4. Exploratory study of Cyanobacteria concentration (lncyan) and Secchi disk depth (lnsd) related to different concentrations of turbidity concentration, suspended solids concentration, concentration of total phosphorous, concentration of TKN, chlorophyll-a concentration, concentration of dissolved oxygen, and zones of the Itaipu Reservoir and quarters of sampling. In this table: a) lnturb, logarithm of the turbidity concentration, expressed in NTU; b) lnss, logarithm of suspended solids concentration, expressed in $\mathrm{mg} / \mathrm{L}$; c) lntp, logarithm of the concentration of total phosphorous, expressed in mg/L; d) lntkn, logarithm of the concentration of TKN, expressed in $\mathrm{mg} / \mathrm{L}$; e) lnchlor, logarithm of the chlorophyll-a concentration, expressed in $\mathrm{mg} / \mathrm{m}^{3}$; f) lnsox, logarithm of the concentration of dissolved oxygen, expressed in $\mathrm{mg} / \mathrm{L}$.

\begin{tabular}{|c|c|c|c|c|c|}
\hline & \multirow{2}{*}{ Wilks' $\lambda$} & \multicolumn{2}{|c|}{ Lnchyan } & \multicolumn{2}{|c|}{ Lnsd } \\
\hline & & $F$ & $p$ & $F$ & $p$ \\
\hline Lnturb & $0.806\left(\mathrm{~F}_{2,68}=8.204 ; p=0.001\right)$ & 14.249 & 0.000 & 5.408 & 0.023 \\
\hline Lnss & $0.920\left(\mathrm{~F}_{2,68}=2.960 ; p=0.059\right)$ & 0.268 & 0.606 & 4.964 & 0.029 \\
\hline Lntp & $0.948\left(\mathrm{~F}_{2,68}=0.563 ; p=0.572\right)$ & 0.016 & 0.901 & 1.131 & 0.291 \\
\hline Lntkn & $0.953\left(\mathrm{~F}_{2,68}=1.695 ; p=0.191\right)$ & 1.394 & 0.242 & 2.724 & 0.103 \\
\hline Lnchlor & $0.840\left(\mathrm{~F}_{2,68}=6.493 ; p=0.003\right)$ & 12.657 & 0.001 & 0.004 & 0.951 \\
\hline Lnsox & $0.792\left(\mathrm{~F}_{2,68}=8.905 ; p=0.000\right)$ & 0.016 & 0.900 & 17.447 & 0.000 \\
\hline Quarter & $0.796\left(\mathrm{~F}_{6,136}=2.736 ; p=0.015\right)$ & 0.137 & 0.938 & 5.170 & 0.003 \\
\hline Zone & $0.683\left(\mathrm{~F}_{4,136}=7.151 ; p=0.000\right)$ & 8.075 & 0.001 & 5.027 & 0.009 \\
\hline
\end{tabular}

\subsubsection{MANCOVA 2}

Using the same procedure as before, a second MANCOVA was applied to the two response variates; these were logarithm of the concentration of total phosphorous (lntp) and logarithm of the concentration of TKN (lntkn). The factors included in the model were Zones and Quarter, and covariates included in the model were lnchlor, lncyan, lnclad, lncop, lnpisc, lnomn, lndetr, lnilio and lnzoopl.

This MANCOVA indicated that no covariate or factor was significant when explaining the concentrations of total phosphorous and TKN (Table 5).

\subsubsection{ANCOVA}

The scatterplots between lnchlor $\times$ lnturb, lnchlor $\times$ lnss, lnchlor $\times$ lntp and lnchlor $\times$ lntkn were inspected, and the relationships were linear. The components tested in the initial model were the Zone and Quarter factors. The covariates tested were: lnturb, lnss, lntp and lntkn.

The complete model initially tested was:

$$
\text { lnchlor }=\mu+\text { zone }+ \text { quarter }+ \text { zone } * \text { quarter }+\operatorname{lnturb}+\operatorname{lnss}+\operatorname{lntp}+\operatorname{lntkn}+\varepsilon
$$

And the minimum model is:

$$
\text { lnchlor }=\mu+\text { zone }+ \text { quarter }+ \text { zone } * \text { quarter }+\operatorname{lntkn}+\varepsilon
$$

This was the model that best explained the relationship among the chlorophyll-a concentration, the concentration of TKN and the reservoir zone and quarter. As the interactions lntkn $\times$ zone and $\ln k n \times$ quarter were not significant, the lines were parallel.

The residual analysis of (2) did not show any trend between the residuals and the estimated values. The residuals were determined to be not normal because their distribution was asymmetrical to the left and leptokurtic, but the model was accepted because the design was balanced [44].

A multiple comparison test between the means (Table 6) showed that there are no differences between all of the reservoir zones for the chlorophyll-a concentrations.

\section{Discussion}

The trophic cascade hypothesis in lakes and reservoirs is based on the fact that each trophic level of the food chain is inversely and directly related to the trophic levels below or above it, following two principles: i) the loss of energy between successive trophic levels and ii) the disturbances in the trophic level affect the remain- 
Table 5. Exploratory study of the concentrations of total phosphorus (lntp) and TKN concentration (lntkn) associated with different concentrations of chlorophyll-a, Cyanobacteria, Cladocera, Copepoda, biomass of piscivorous fish, biomass of omnivorous fish, biomass of detritivorous fish, biomass of iliophagous fish, biomass of zooplanktophagous fish, and zones of Itaipu Reservoir and quarters of sampling. Where a) lnchlor, logarithm of the chlorophyll-a concentration, expressed in $\mathrm{mg} / \mathrm{m}^{3}$; b) lncyan, logarithm of the cyanobacteria concentration, expressed in cell $/ \mathrm{mL}$; c) lnclad, logarithm of the Cladocera concentration, expressed in organism/mL; d) lncop, logarithm of the Copepoda concentration, expressed in organism/mL; e) lnpisc, logarithm of the biomass of piscivorous fishes, expressed in kg; f) lnomn, logarithm of the biomass of omnivorous fishes, expressed in kg; g) lndetr, logarithm of the biomass of detritivorous fishes, expressed in kg; h) lnilio, logarithm of the biomass of iliophagous fishes, expressed in kg; i)lnzoopl, logarithm of the biomass of zooplanktophagous fishes, expressed in $\mathrm{kg}$.

\begin{tabular}{|c|c|c|c|c|c|}
\hline & \multirow{2}{*}{ Wilks' $\lambda$} & \multicolumn{2}{|c|}{ Intp } & \multicolumn{2}{|c|}{ Intkn } \\
\hline & & $F$ & $p$ & $F$ & $p$ \\
\hline Lnchlor & $0.959\left(\mathrm{~F}_{2,60}=1.290 ; p=0.283\right)$ & 1.957 & 0.167 & 1.345 & 0.251 \\
\hline Lncyan & $0.942\left(\mathrm{~F}_{2,60}=1.858 ; p=0.165\right)$ & 3.216 & 0.078 & 1.444 & 0.234 \\
\hline Lnclad & $0.976\left(\mathrm{~F}_{2,60}=0.758 ; p=0.487\right)$ & 1.393 & 0.243 & 0.001 & 0.976 \\
\hline Lncop & $0.935\left(\mathrm{~F}_{2,60}=2.070 ; p=0.135\right)$ & 3.676 & 0.060 & 1.477 & 0.229 \\
\hline Lnpisc & $0.970\left(F_{2,60}=0.920 ; p=0.404\right)$ & 0.380 & 0.540 & 1.023 & 0.316 \\
\hline Lnomn & $0.977\left(\mathrm{~F}_{2,60}=0.730 ; p=0.499\right)$ & 0.025 & 0.874 & 1.210 & 0.276 \\
\hline Lndetr & $0.983\left(\mathrm{~F}_{2,60}=0.507 ; p=0.605\right)$ & 0.125 & 0.725 & 1.023 & 0.316 \\
\hline Lnilio & $0.954\left(\mathrm{~F}_{2,60}=1.463 ; p=0.240\right)$ & 1.611 & 0.209 & 2.144 & 0.148 \\
\hline Lnzoopl & $0.996\left(\mathrm{~F}_{2,60}=0.123 ; p=0.884\right)$ & 0.239 & 0.626 & 0.001 & 0.978 \\
\hline Quarter & $0.910\left(\mathrm{~F}_{6,120}=0.969 ; p=0.450\right)$ & 1.228 & 0.307 & 1.314 & 0.278 \\
\hline Zone & $0.932\left(\mathrm{~F}_{4,120}=1.070 ; p=0.375\right)$ & 1.008 & 0.371 & 1.730 & 0.186 \\
\hline
\end{tabular}

Table 6. Comparison of the mean of chlorophyll-a (lnchlor = logarithm of chlorophyll-a, expressed in mg/L) in the Itaipu reservoir zones, quarters and interactions.

\begin{tabular}{cccc}
\hline Reservoir zone & Adjusted mean Inchlor $\left(\mathrm{mg} / \mathrm{m}^{3}\right) \pm$ ep & Comparison & $\mathrm{t}$ test \\
\hline Fluvial (F) & $1.352(3.87) \pm 0.088$ & $\mathrm{~F} \times \mathrm{T}$ & $1.8140 \mathrm{~ns}$ \\
Transition (T) & $2.273(9.71) \pm 0.090$ & $\mathrm{~F} \times \mathrm{L}$ & $-0.4018 \mathrm{~ns}$ \\
Lacustrine (L) & $1.883(6.57) \pm 0.088$ & $\mathrm{~T} \times \mathrm{L}$ & $0.9394 \mathrm{~ns}$ \\
\hline
\end{tabular}

ing levels. Studies testing this hypothesis in lakes and temperate reservoirs are countless [6] [7] [11] [17] [23] [28] [45]. In tropical lakes, these studies are still scarce [27] [35] [46]-[49]. The top-down effects in temperate lakes are explained by [17] [20], in which the relationships among the trophic levels led to a negative effect from the piscivory in the lower levels.

The top-down direct effect was found in the first trophic level, and the piscivorous biomass presented a positive correlation, indicating a control absence upon the insectivorous, benthivorous, zooplanktophagous and iliophagous, whose biomasses increased. This result suggests that the piscivorous might have an effect in the reservoir water quality when the indirect relationships among the predated guilds, except insectivorous, were not shown to have had a controlling effect, except the detritivorous, which had a negative correlation with the chlorophyll-a. The piscivorous controlling effect was also pointed out by [50] in 31 reservoirs of the State of Paraná.

Predation has an important effect in the sense that it controls the excess of available prey, which allows them to survive under limited food conditions, especially when prey reproduction rate is very high, as in the case of tilapia [1]. In systems with high fish densities, a loss in individual weight and higher death rates can be observed [17]. The presence of predators increases a system's stability because when there is predation, there is a decreasing in the prey, which prevents food scarcity. In a study of several reservoirs in NE Brazil, [51] showed 
that the number of predator fish species interferes with a reservoir's trophic dynamics. They observed that, in reservoirs with only two predator species, commercial catches are higher, and in reservoirs with less than two predator species, competition among the prey probably lead to decreases in catch size.

Several authors suggest that freshwater community structure and biomass are regulated by predators [6] [7] [11] [23]. It can be said that an increase of piscivorous biomass is associated with planktivorous biomass reduction and with an increasing, large zooplankton biomass phytoplankton reduction [11] [17]. The interactions resulting from predation can promote the reduction of planktivorous biomass and are associated with the increase of large zooplankton biomass and the increase of algae consumers (grazing), which reduces phytoplankton biomass.

The presence of predators is important to changing the zooplankton biomass [52]. According to the trophic cascade hypothesis, an increase of piscivorous or carnivorous fish in a lake or reservoir induces a decrease in planktivorous biomass, which increases zooplankton biomass and reduces phytoplankton biomass [7] [11].

The omnivorous fish exhibited negative effects compared to the zooplanktophagous and positive effects in relation to the detritivorous and iliophagous. The fish communities of tropical and subtropical lakes are frequently dominated by omnivorous species, which have great feeding plasticity and can consume zooplankton, phytoplankton, periphyton, bentonic macroinvertebrates and debris. According to [35], piscivorous fish are represented by few species and have a comparatively small biomass; a larger biomass of small carnivorous and omnivorous fish usually dominates the trophic chain.

Some omnivorous fish species are neither controlled by the readiness of feeding resources (zooplankton) nor by the predation pressure, as they are usually larger than their potential predators [53]. The top-down control exerted by piscivorous fish is, therefore, less intense in subtropical/tropical lakes than in temperate lakes. reference [54] discussed the effect of the planktivory in lakes and reservoirs in Brazil, pointing out the predation effects, the feeding types and alimentary selectivity, the effects of larval fishes and alevins, nutrient availability and the lake's trophic degree and hydrology. The MANCOVA in this paper did not present any significant relationship between the fish biomasses and phyto and zooplankton abundances with the response variates of the total phosphorous and TKN, indicating that there is no top-down control in the Itaipu reservoir.

The effect of the omnivorous fish upon other trophic groups of fish (Pimelodus maculatus and Pterodoras granulosus, for example) was also observed. This analysis indicates that an increase of omnivorous fish biomass caused the depletion of the zooplanktophagous fish biomass, unlike what occurred with the detritivorous and iliophagous fish, whose biomass increased. When the omnivorous filterers dominate the planktivorous, the hypothesis of "fish versus lake trophic states" does not remain valid as growth stimulation by the omnivorous fish is intensified by an increase of nutrient loads [55].

Reference [56] pointed out that a factor that complicates the trophic cascade hypothesis is the supposition that all planktivorous fish populations are susceptible to the increase of piscivorous fish biomass. Reference [57] also suggested that morphological characteristics (such as buccal opening of the predators) and the prey's refuge habitat were factors of extreme importance to the trophic cascade hypothesis.

Almost all groups of fishes (Piscivorous, Insectivorous, Detritivorous, Bentophagous, Iliophagous, and Zooplanktophagous) presented positive and significant direct relationships with the macrozooplankton, i.e., Cladocera and Copepoda. These results suggest that this increase led to in an increase of the herbivorous zooplankton, indicating that the pressure from the fish does not control the zooplankton communities, which are able to consume phytoplankton; this appeared to be a bottom-up effect. Macrozooplankton presented a positive effect with chlorophyll-a and with cyanobacteria concentrations. Studies in 31 reservoirs in the State of Paraná showed the same positive $(p<0.01)$ relationship between the macrozooplankton and chlorophyll-a [58] [59]. Positive relationships between zooplankton and chlorophyll were also detected in the State of Paraná reservoirs, and [28] also found these relationships in the Itaipu reservoir.

According to [20], in tropical ecosystems, prey are not strictly zooplanktivorous but are also omnivorous and do not have a direct effect upon the zooplankton community. Systems dominated by omnivorous fish present weak trophic connections due to a combination of muffled mechanisms. As a consequence, these systems are difficult to forecast using the trophic cascade hypothesis. Among the involved mechanisms, [35] commented on "intraguild predation" (IGP), which applies to omnivorous fish feeding upon herbivorous zooplankton and phytoplankton and the ontogentic omnivory (the same mechanism that appears during fish ontogeny from the juvenile to the adult phase). The absence of the effect of zooplanktophagous predation shown in the statistical analysis also indicated deterioration of the water quality, with a positive effect related to chlorophyll and cyanobacte- 
ria. Reference [60] pointed out the great adaptability that zooplanktophagous have in a branchial system, with long, big, fine and numerous filaments and that the Hypophthalmus edentatus filtration mechanism is of the displacement type with passive filtration, consisting of open mouth swimming with dilated opercula and essentially a zooplankton diet. These results stress the importance of the omnivore and detritivory chains in the tropical and subtropical aquatic habitats. These results corroborated the findings of [20] [35], who emphasized the effect of the omnivorous and the detritivorous food chains in these places.

Reference [20] mentioned that, in many of the studies concerning the impact of planctivorous fish, the feeding behavior of the studied species had not yet been determined, and as a consequence, the mechanisms that determine the food selectivity and the use of resources are still not well understood. The author explained that fish are capable of changing their patterns of food selection, classifying the fish according to their feeding habits. These habits were particle visual, filtration by pumping and filtration by trawling. In the case of the first two, several factors influenced the success of predation, such as the prey size and light intensity. Young fish species that feed with the particle visualization method change to the filtration by pumping method when they become adults. Reference [15] showed this effect in lab experiments on the cichlid Geophagus brasiliensis. Reference [54] tested the food selectivity for the same species in experiments in mesocosmos in situ in the Lobo-Broa Reservoir (SP). The authors verified that the biomass of Daphnia sp. decreased in the treatments with fish, proving the pressure for food selectivity and corroborating the [15] laboratory studies.

The low pressure that fish exert upon the zooplankton implies the dominance of small-sized individuals in tropical and subtropical lakes [20]. The biomass of omnivorous copepods is usually dominant in oligomesotrophic systems, and the microzooplankton prevails in more eutrophic systems. At high temperatures, the daily fluctuations of the physical and chemical conditions or sudden environmental changes (due to heavy rains, for instance) might alter the zooplanktonic community (increasing the number of protozoa and rotifers), which have the capacity to recover very quickly. The classical control of phytoplankton by macrozooplankton in temperate lakes is not frequently seen in tropical lakes [20] [48] [49]. This absence of pressure upon the zooplankton might represent an additional limitation in the biomanipulation difficulty in tropical and subtropical lakes. In a mesocosmos study, [61] verified that a predator caused a strong impact upon the planktivorous community, but the interactions of the trophic levels beneath these communities did not show a strong effect upon the zooplankton and phytoplankton communities.

Reference [35] stated that the top-down effects in tropical habitats were more complex than in temperate ones, where essentially zooplanktophagous species were not found; rather, there were omnivorous species, such as tilapia. Additionally, the piscivorous species gave way to the macro-carnivores. Chlorophyll-a concentration increases along with the biomass of omnivorous fish and decreases with the macro-carnivores species' biomass. However, in this paper, chlorophyll-a concentration did not show a significant relationship with the global biomass of fish and the macro-zooplankton biomass. The interactions are related to the trophic state. The regulation of fish-phytoplankton, originated by the complexity of the interactions of the omnivorous species, was present in the feeding behavior of several consumer populations.

The concentration of TKN is a nutrient form that most influenced primary production (expressed by the concentration of chlorophyll-a and cyanobacteria). Total phosphorous also increased the concentration of cyanobacteria. This type of relationship is contrary to the one commonly found in temperate lakes and dams [8] [17] indicating a bottom-up effect. The last level analyzed the trophic level, confirming the bottom-up effect. This was the chlorophyll-nutrient interaction in which an increase of chlorophyll concentrations correlated positively with the total phosphorous concentrations. In temperate ecosystems, this relationship is positive, and concentrations of nutrients control the chlorophyll concentration. The ANCOVA did not show any difference in the chlorophyll-a concentration between the reservoir zones.

Reference [62] compared the phosphorous excretion rate for planktivorous fish and estimated the internal and external loads in the eutrophic Finjasjon Lake in Sweden. The experiments were done in a laboratory using two prey species, one benthonic and one pelagic. The results were extrapolated to the whole lake using the calculation of the prey consumption by predator fish, which was based on field data of the community's structure, excretion rate growth and fish diet. The phosphorous rate excreted by the fish was $0.53 \mathrm{mg} \mathrm{P} / \mathrm{m}^{2} / \mathrm{d}$ on average, which showed an increase of $110 \%$ of external load and $42 \%$ of internal load. Most of the phosphorous excreted by fish was recycled inside the water column, that is, more than $18 \%$ of the phosphorous excreted in the water comes from the ingested benthos and represented the phosphorous transport from the sediment to the water column. The phosphorous excreted by the fish was available to the phytoplankton, suggesting that the nutrients 
may be an important source of sustenance for the algae.

Fish liberate phosphorous directly into the water through metabolic processes (excretion) and, indirectly, due to the behavior of turning over the sediment in search for food, making the nutrient available to the water column [62] [63]. Reference [21] emphasized that the importance of the fish to the maintenance of the phosphorous concentrations in the water may be greater than that from allochthonous sources, mainly as a nutrient source in the pelagic zone. Reference [64] pointed out that the soluble phosphorous is the main form excreted by the fish, and [21] showed that tilapia is the fish that presents the largest excretion rate of soluble phosphorous in Lake Paranoá, Brazil.

The indirect relationships indicate an absence of chlorophyll-a and cyanobacteria control by the piscivorous, benthivorous, iliophagous and zooplanktophagous fish. These fish groups can be employed to improve the reservoir water quality, where laboratory experiments and in situ (mesocosmos) might be able to assist in environmental management. In addition, these findings indicate that these fish groups compelled the primary productivity development.

Reference [35] investigated the effects of trophic cascades in 13 reservoirs in Pernambuco (Brazil). The relationships, which are usually well explained in lakes and temperate reservoirs, were not evident in tropical lakes. The authors suggested that the state of the fish trophic guilds played an important role in the food chains in these reservoirs, where indirect effects between the chlorophyll concentration and the densities of omnivorous fish present positive relationships, indicating that the omnivorous fish cause pressure upon chlorophyll development. According to [49], this pressure is due to the fact that fish species richness is frequently higher in tropical and subtropical lakes. South America and Africa have very rich freshwater fish fauna, and many of these fish species show partial niche overlapping, increasing their control over prey [20]. This finding was also detected by [65] in lakes located in the southern areas of the United States.

The analyses suggest that the increase in insectivorous and herbivorous fish contributed to the decrease in concentration of total phosphorous in the reservoir. There was a positive relationship between chlorophyll-a and cyanobacteria, indicating that the increase of the concentration of the chlorophyll-a was related to the increase of cyanobacteria density.

The MANCOVA 1 explains how the variates of turbidity concentration (Inturb) and dissolved oxygen (Insox), aside from the zone and quarter factors, influence cyanobacteria concentration and Secchi disk depth. The MANCOVA 1 showed the effects of turbidity concentration, dissolved oxygen, the reservoirs zones and the quarters on the water's transparency (Secchi disk depth). The turbidity concentration, chlorophyll-a concentration and reservoir zone had significant effects upon cyanobacteria concentration.

The detritivorous fish group was the trophic guild that presented a controlling effect on chlorophyll-a, indicating that the increase in these fish groups depleted the chlorophyll concentration in the reservoir. The second MANCOVA applied indicated that no covariates (primary production, macrozooplankton and fishes) or factors (reservoir zone and quarter) were significant when explaining the concentrations of total phosphorous and TKN, which are the most important nutrients assimilated by chlorophyll-a. Therefore, measures like capturing these species in greater numbers and sport fisheries would increase the water quality of the reservoir.

When analyzing the direct relationships from one trophic level to another, we observed that the reservoir of Itaipu shows strong evidence of a bottom-up force, with positive effects in all levels. Only the analyses of the predation effect of fish showed negative relationships, and the relationship between detritivorous and macrozooplankton indicated a top-down effect. These results corroborated the findings of [28] in the reservoir of Itaipu and [48] in the Bolivian lake experiments, showing direct and indirect effects in the trophic cascade. The cycle of the trophic chain can be explained by the detritivorous fish biomass, an effect observed in tropical and subtropical ecosystems that is of extreme importance to the indirect relationships and determines the controlling forces of the primary productivity in the reservoir.

\section{Conclusions}

It is important to note that the reservoir of Itaipu, located in a subtropical area, receives large tributaries (the Paranapanema, Tietê and Grande rivers) from the State of São Paulo, located in the tropical area. It is possible that the reservoir of Itaipu might have a strong influence on tropical systems. It is also possible that the reservoir cascade system above Itaipu has an influence on food chain dynamics. Studies using this same approach and including other variates, such as macrophytes biomass, birds of prey and benthos macroinvertebrates, might help to solve these problems. The food chain of a reservoir is represented by several groups of organisms based on 
their ways of life and feeding habits. The groups of organisms are mutually related, mainly by their feeding habits, by their allelopathic reactions, by the behavioral reactions and by nutrient recycling. The authors emphasized that it is important to understand the aquatic organisms and the food chain of a reservoir, where the presence and absence of certain species and the food chain serve as a long-term indicator of the water quality.

Catch and effort data regarding professional and amateur fishing over a long period of time, as found in Itaipu, are of extreme importance as they may help to improve our knowledge of fishing productivity, metabolism of the ecosystem and the dynamics of the structure of the fish species in the reservoir.

Experiments in laboratory and in the field (in situ) scaled with the use of mesocosmos and limno-corrals will be better able to explain the implications of the trophic relationships of the system. This type of research is valuable, and proper models that evaluate the trophic operation of lakes and reservoirs may be an important tool that can be used by the groups that determine the use of water resources in Brazil.

\section{Acknowledgements}

This paper is part of a postdoctoral report submitted by the senior author to the Programa de Pós Graduação em Ciências Biológicas-Zoologia (IB-UNESP, Rio Claro), under MPJr supervision. We thank FAPESP (Processo no. 07/50986-9), CNPq, UNESP, UEM/Nupelia and ITAIPUBINACIONAL for their financial support and facilities and David Hoeinghaus for suggestions that improved the manuscript. Miguel Petrere Juniorand Ângelo Antonio Agostinhoare recipients of research fellowships from CNPq.

\section{References}

[1] Odum, E.P. (1988) Ecologia. Guanabara, Koogan AS, Rio de Janeiro.

[2] Wetzel, R.G. (1993) Limnologia. Fundação Calouste Gulbenkian.

[3] Calijuri, M.C., Tundisi, J.G., Henry, R., Ibañez, M.S.R., Matsumura-Tundisi, T. and Rocha, O. (1997) Changes in Light Attenuation in Fifteen Lakes and Its Relationship with Chlorophyll and Particulate Material, during Summer and Winter. In: Saijo, Y. and Tundisi, J.G., Eds., Limnological Studies in Rio Doce Valley Lakes, Brazil, Nagoya University, Nagoya.

[4] Henry, R. (1990) Amônia ou fosfato como agente estimulador do crescimento do fitoplâncton na represa de Jurumurim (Rio Paranapanema, SP)? Revista Brasileira de Biologia, 50, 883-892.

[5] Overbeck, J. (2000) Conceitos de Ecossistema. In: Jørgensenand, S.E. and Vollenweider, R.A., Eds., Diretrizes para o Gerenciamento de Lagos. Princípios para o Gerenciamento de Lagos.

[6] Hrbáček, J., Dvoráková, M., Korínek, V. and Procházková, L. (1961) Demonstration of the Effect of the Fish Stock on the Species Composition of Zooplankton and the Intensity of the Whole Plankton Association. Verhandlungen des Internationalen Verein Limnologie, 14, 192-195.

[7] Shapiro, J., Lamarra, V. and Lynch, M. (1975) Biomanipulation, an Ecosystem Approach to Lake Restoration. In: Brezonik, P. and Fox, F., Eds., Proceedings of the Symposium Water Quality Management through Biological Control, Department of Environmental Engineering Sciences, University of Florida, Gainesville, 85-96.

[8] Carpenter, S.R. and Kitchell, J.F. (1993) The Trophic Cascade in Lakes. Cambridge University Press, Cambridge. http://dx.doi.org/10.1017/CBO9780511525513

[9] Demelo, R., France, R. and McQueen, J.D. (1992) Biomanipulation: Hit or Myth? Limnology and Oceanography, 37, 192-207. http://dx.doi.org/10.4319/lo.1992.37.1.0192

[10] McQueen, J.D., Post, J.R. and Mills, E.L. (1986) Trophic Relationships in Freshwater Pelagic Ecosystems. Canadian Journal of Fisheries and Aquatic Sciences, 43, 1571-1581. http://dx.doi.org/10.1139/f86-195

[11] Carpenter, S.R., Kitchell, J.F. and Hodgson, J.R. (1985) Cascading Trophic Interactions and Lake Productivity Fish: Predation and Herbivory Can Regulate Ecosystems. BioScience, 35, 634-639. http://dx.doi.org/10.2307/1309989

[12] Brett, M.T. and Goldman, C.R. (1996) A Meta-Analysis of the Fresh-Water Trophic Cascade. Proceedings of the National Academy of Sciences of the United States of America, 93, 7723-7726. http://dx.doi.org/10.1073/pnas.93.15.7723

[13] Brett, M.T. and Goldman, C.R. (1997) Consumers versus Resource Control in Freshwater Pelagic Food Webs. Science, 275, 384-386. http://dx.doi.org/10.1126/science.275.5298.384

[14] Elser, J.J. and Goldman, C.R. (1991) Zooplankton Effects on Phytoplankton in Lakes of Contrasting Trophic Status. Limnology and Oceanography, 36, 64-90. http://dx.doi.org/10.4319/10.1991.36.1.0064

[15] Lazzaro, X.T. (1991) Feeding Convergence in South American and African Zooplaktivorous Cichlids Geophagus brasiliensis and Tilapia rendalli. Environmental Biology of Fishes, 31, 283-293. http://dx.doi.org/10.1007/BF00000693 
[16] Jeppesen, E., Jensen, J.P., Sondergaard, M., Lauridsen, T., Pedersen, J. and Jensen, L. (1997) Top-Down Control in Freshwater Lakes: The Role of Nutrient State, Submerged Macrophytes and Water Depth. Hydrobiologia, 342/343, 151-164. http://dx.doi.org/10.1023/A:1017046130329

[17] McQueen, D.J. (1990) Manipulating Lake Community Structure: Where Do We Go from Here? Freshwater Biology, 23, 613-620. http://dx.doi.org/10.1111/j.1365-2427.1990.tb00299.x

[18] Hambright, K.D. (1994) Morphological Constraints in the Piscivore-Planktivore Interaction: Implications for the Trophic Cascade Hypothesis. Limnology and Oceanography, 39, 897-912. http://dx.doi.org/10.4319/lo.1994.39.4.0897

[19] McQueen, D.J., France, R. and Kraft, C. (1992) Confounded Impacts of Planktivorus Fish on Freshwater Biomanipulations. Archiv für Hydrobiologie, 125, 1-24.

[20] Lazzaro, X.T. (1997) Do the Trophic Cascade Hypothesis and Classical Biomanipulation Approaches Apply to Tropical Lakes/Reservoirs? Verhandlungen des Internationalen Verein Limnologie, 26, 719-730.

[21] Starling, F.L.R.M. (1998) Development of Biomanipulation Strategies for the Remediation of Eutrophication Problem in a Urban Reservoir-Lago Paranoá. Ph.D. Thesis, University of Stirling, Escócia.

[22] Perrow, M., Meijer, M.L., Dawidowicz, P. and Coops, H. (1997) Biomanipulation in Shallow Lakes: State of the Art. Hydrobiologia, 342/343, 355-365. http://dx.doi.org/10.1023/A:1017092802529

[23] Persson, A., Andersson, G., Hamrin, S.F. and Johansson, L. (1988) Predator Regulation and Primary Production along the Productive Gradient of Temperate Lake Ecosystems. In: Carpenter, S.R. Ed., Complex Interactions in Lake Communities, Springer-Verlag, Berlin, 45-65. http://dx.doi.org/10.1007/978-1-4612-3838-6_4

[24] Prejs, A., Pijanowska, J., Koperski, P., Martyniak, A., Borón, S. and Hliwa, P. (1997) Food-Web Manipulation in a Small, Eutrophic Lake Wirbel, Poland: Long-Term Changes in Fish Biomass and Basic Measures of Water Quality. A Case Study. Hydrobiologia, 342/343, 383-386.

[25] Hairston Jr., N.G. and Hairston Sr., N.G. (1997) Does Food Web Complexity Eliminate Trophic-Level Dynamics? American Naturalist, 149, 1001-1007. http://dx.doi.org/10.1086/286035

[26] Mehner, T., Hölker, F. and Kasprzak, P. (2005) Spatial and Temporal Heterogeneity of Trophic Variables in a Deep Lake as Reflected by Repeated Singular Samplings. OIKOS, 108, 401-409. http://dx.doi.org/10.1111/j.0030-1299.2005.13338.x

[27] Quirós, R. and Boveri, M.B. (1999) Fish Effects on Reservoir Trophic Relationships. In: Tundisi, J.G. and Straškraba, M., Ed., Theoretical Reservoir Ecology and Its Applications, IIE, BAC, Backhuys Publishers, Leiden, 529-564.

[28] Ribeiro-Filho, R.A. (2006) Relações tróficas e limnológicas no reservatório de Itaipu: Uma análise do impacto da biomassa pesqueira nas comunidades planctônicas. Ph.D. Thesis, Escola de Engenharia de São Carlos, Universidade de São Paulo, São Paulo.

[29] Filho, R.A.R., de Almeida Pereira, J.M., Júnior, M.P. and Benassi, S.F. (2013) Eutrophication Indexes Used as Fish Production Parameters in the Itaipu Reservoir (Brazil). Journal of Environmental Protection, 4, 151-178. http://dx.doi.org/10.4236/jep.2013.47A018

[30] Garcia, S.M., Kerbi, A., Aliaume, C., Do Chi, T. and Lasserre, G. (2003) The Ecosystem Approach to Fisheries. FAO Fisheries Technical Paper, 43, FAO, Rome.

[31] Agostinho, A.A., Pelicice, F.M. and Gomes, L.C. (2008) Dams and the Fish Fauna of the Neotropical Region: Impacts and Management Related to Diversity and Fisheries. Brazilian Journal of Biology, 68, 1119-1132. http://dx.doi.org/10.1590/S1519-69842008000500019

[32] Thornton, K.W., Kennedy, R.H., Carroll, J.H., Walker, W.W., Gunkel, R.C. and Ashby, S. (1981) Reservoir Sedimentation and Water Quality_An Heuristic Model. In: Stefan, H.G., Ed., Proceedings of the Symposium on Surface Water Impoundments, American Society of Civil Engineers, Minneapolis, 654-661.

[33] Pagioro, T.A. and Thomaz, S.M. (2002) Longitudinal Patterns of Sedimentation in a Deep, Monomictic Subtropical Reservoir (Itaipu, Brazil-Paraguay). Archiv für Hydrobiologie, 154, 515-528.

[34] Hahn, N.S., Agostinho, A.A., Gomes, L.C. and Bini, L.M. (1998) Estrutura trófica da ictiofauna do reservatório de Itaipu (Paraná-Brasil) nos primeiros anos de sua formação. Interciência, 23, 299-305.

[35] Lazzaro, X.T., Bouvy, M., Ribeiro-Filho, R.A., Oliveira, V.S., Sales, L.T., Vasconcelos, A.R.M. and Mata, M.R. (2003) Do Fish Regulate Phytoplankton in Shallow Eutrophic Northeast Brazilian Reservoirs? Freshwater Biology, 48, 649668. http://dx.doi.org/10.1046/j.1365-2427.2003.01037.x

[36] Srivastava, M.S. and Cartes, E.M. (1983) Introduction to Applied Multivariate Statistics. Elsevier, Amsterdam.

[37] Morrison, D.F. (1990) Multivariate Statistical Methods. 3rd Edition, McGraw-Hill, New York.

[38] Everitt, B.S. and Dunn, G. (1995) Applied Multivariate Data Analysis. Edward Arnold, London.

[39] Tabachnick, B.G. and Fidell, L.S. (2001) Using Multivariate Statistics. 4th Edition, Allyn and Bacon, Boston. 
[40] Petrere Júnior, M. (1978) Pesca e esforço no Estado do Amazonas. I. Esforço e captura por unidade de esforço. Acta Amazonica, 8, 439-454.

[41] Petrere Júnior, M. (1983) Yield per recruit of the Tambaqui, Colossoma macropomum Cuvier, in the Amazonas State. Journal of Fish Biology, 22, 133-144. http://dx.doi.org/10.1111/j.1095-8649.1983.tb04733.x

[42] Petrere Júnior, M. (1986) Amazon Fisheries. II-Variations in the Relative Abundance of Tucunaré (Cichlaocellaris, C. temensis) Based on Catch and Effort Data of the Trident Fisheries. Amazoniana, 10, 1-13.

[43] Kotas, J.E. (2004) Dinâmica de populações e pesca do tubarão martelo Sphyrnalewini (Grffith \& Smith, 1834) capturado no mar territorial e Zona Econômica Exclusiva do sudeste-sul do Brasil. Ph.D. Thesis, Escola de Engenharia de São Carlos, Universidade de São Paulo, São Paulo.

[44] Huitema, B.E. (1980) The Analysis of Covariance and Alternatives. John Wiley \& Sons, Hoboken.

[45] Benndorf, J., Böing, W., Koop, J. and Neubauer, I. (2002) Top-Down Control of Phytoplankton: The Role of Time Scale, Lake Depth and Trophic State. Freshwater Biology, 47, 2282-2295. http://dx.doi.org/10.1046/j.1365-2427.2002.00989.x

[46] Scasso, F., Mazzeo, N., Gorga, J., Kruk, J., Lacerot, G., Clemente, J., Fabian, D. and Bonilla, S. (2001) Limnological Changes in a Sub-Tropical Shallow Hypertrophic Lake during Its Restoration: Two Years of a Whole-Lake Experiment. Aquatic Conservation: Marine and Freshwater Ecosystems, 11, 31-44. http://dx.doi.org/10.1002/aqc.420

[47] Hasan, M.R., Mondal, M.A.W., Miah, M.I. and Kibria, M.G. (2001) Water Quality Study of Some Selected Oxbow Lakes with Special Emphasis on Chlorophyll-a. In: De Silva, S.S., Ed., Reservoir and Culture-Based Management Fisheries: Biology and Management, ACIAR, Canberra, 126-136.

[48] Rejas, D., Clerck, L., Auwerkerken, J., Tak, P. and Meester, L. (2005) Plankton Dynamics in a Tropical Floodplain Lake: Fish, Nutrients, and the Relative Importance of Bottom-Up and Top-Down Control. Freshwater Biology, 50, 5269. http://dx.doi.org/10.1111/j.1365-2427.2004.01306.x

[49] Jeppesen, E., Søndergaard, M., Mazzeo, N., Meerhoff, M., Branco, C.C., Huszar, V. and Scasso, F. (2005) Lake Restoration and Biomanipulation in Temperate Lakes: Relevance for Subtropical and Tropical Lakes. In: Reddy, M.V. and Moss, B., Eds., Restoration and Management of Tropical Eutrophic Lakes, Science Publishers, Enfield, 341-359.

[50] Pelicice, F.M., Abujanra, F., Fugi, R., Latini, J.D., Gomes, L.C. and Agostinho, A.A. (2005) A Piscivoria Controlando a Produtividade em Reservatórios: Explorando o Mecanismo Top Down. In: Rodrigues, L., Thomaz, S.M., Agostinho, A.A. and Gomes, LC., Eds., Biocenose em Reservatórios: Padrões espaciais e temporais, Rima, São Carlos, 293-302.

[51] Paiva, M.P., Petrere Jr., M., Petenate, A.J., Nepomuceno, F.H. and Vasconcelos, E.A. (1994) Relationship between the Number of Predatory Fish Species and Fish Yield in Large Northeastern Brazilian Reservoirs. In: Cowx, I.G., Ed., Rehabilitation of Freshwater Fisheries, Fishing News Books, Blackwell, Oxford, 120-129.

[52] Vanni, M.J. and Findlay, D.L. (1990) Trophic Cascades and Phytoplankton Community Structure. Ecology, 71, 921937. http://dx.doi.org/10.2307/1937363

[53] Arcifa, M., Starling, F.L.R.M., Sipaúba-Tavares, L.H. and Lazzaro, X.T. (1995) Experimental Limnology. In: Tundisi, J.G., Bicudo, C.E.M. and Tundisi, T.M., Eds., Limnology in Brazil, ABC/SBL, Rio de Janeiro, 257-282.

[54] Roche, K.F. and Rocha, O. (2005) Aspectos de predação por peixes em lagos e represas, com enfoque na planctivoria. In: Roche, K.F. and Rocha, O., Eds., Ecologia trófica de peixes com ênfase na planctivoria nos ambientes lênticos de água doce no Brasil, Rima, São Carlos, 1-24.

[55] Drenner, R.W., Smith, J.D. and Threlkeld, S.T. (1996) Lake Trophic State and the Limnological Effects of Omnivorus Fish. Hydrobiologia, 319, 213-223. http://dx.doi.org/10.1007/BF00013734

[56] Hambright, K.D., Drenner, R.W. and McComas, S.R. (1991) Gape-Limited Piscivorous, Planktivores Size Refuges, and the Trophic Cascade Hypothesis. Archiv für Hydrobiologie, 121, 389-404.

[57] Hambright, K.D. (1994) Morphological Constraints in the Piscivore-Planktivore Interaction: Implications for the Trophic Cascade Hypothesis. Limnology and Oceanography, 39, 897-912. http://dx.doi.org/10.4319/lo.1994.39.4.0897

[58] Lansac-Tôha, A., Bonecker, C.C. and Velho, L.F.M. (2005) Estrutura da Comunidade Zooplanctônica em Reservatórios. In: Rodrigues, L., Thomaz, S.M., Agostinho, A.A. and Gomes, L.C., Eds., Biocenoses em Reservatórios: Padrões espaciais e temporais, Rima, São Carlos, 115-136.

[59] Piana, P.A., Da Luz, K.D.G., Pelicice, F.M., Costa, R.S., Gomes, L.C. and Agostinho, A.A. (2005) Predição e Mecanismos Reguladores da Biomassa de Peixes em Reservatórios. In: Rodrigues, L., Thomaz, S.M., Agostinho, A.A. and Gomes, L.C., Eds., Biocenose em Reservatórios_Padrões espaciais e temporais, Rima, São Carlos, 303-310.

[60] Abujanra, F. and Agostinho, A.A. (2002) Dieta de Hypophthalmus edentatus (Spix. 1829) (Osteichthyes, Hypophthalmidae) e variações de seu estoque noreservatório de Itaipu. Acta Scientiarum Biological Sciences, 24, 401-410.

[61] Baca, R.M. and Drenner, R.W. (1995) Do the Effects of Piscivorous Largemouth Bass Cascade to the Plankton? Hydrobiologia, 316, 139-151. http://dx.doi.org/10.1007/BF00016895 
[62] Persson, A. (1997) Phosphorus Release by Fish in Relation to External and Internal Load in a Eutrophic Lake. Limnology and Oceanography, 42, 577-583. http://dx.doi.org/10.4319/lo.1997.42.3.0577

[63] Pereira, J.M.A. and Ribeiro-Filho, R.A. (2004) Efeitos da excreção de tilápias (Tilapiarendali e Oreochromisniloticus) em reservatórios e viveiros de piscicultura. In: Espíndola, E.L.G. and Wendland, E., Eds., Bacia Hidrográfica: Diversas abordagens em pesquisa, Rima, São Carlos, 99-109.

[64] Brabrand, A., Faafeng, B. and Nilssen, J.P.M. (1990) Relative Importance of Phosphorus Supply to Phytoplankton Production: Fish Excretion versus External Loading. Canadian Journal of Fisheries and Aquatic Sciences, 47, $364-372$. http://dx.doi.org/10.1139/f90-038

[65] Stein, R.A., Devries, D.R. and Dettmers, J.M. (1995) Food-Web Regulation by a Planktivore: Exploring the Generality of the Trophic Cascade Hypothesis. Canadian Journal of Fisheries and Aquatic Sciences, 52, 2518-2526.

http://dx.doi.org/10.1139/f95-842 